some months past, a fact of which the members of the British Association may take advantage this year. It is now Scotland's turn.

W. H. C.

\section{Ophrys muscifera}

ON the afternoon of June 2, I 878 , I observed some new facts, which, I think, are of importance in eluciclating the hitherto mysterions fertilisation of the Fly-Orchis. In sunny weather and under normal conditions the labellum secretes fluid, and a broad central longitudinal stripe of its surface is covered with small drops. Of fifty fresh flowers $I$ found the labellum in thirteen covered with drops, in twenty-five shining with adhering moisture, in twelve without any conspicuous trace of fluid. The two small shining projections on each side of the base of the labellum (the sham-nectaries of Sprengel) were quite dry in all the flowers. In one flower I saw a fly (Sarcophaga sp.) sitting on the Iabellum and licking the drops. Its head was directed towards the base of the labellum. On my approaching it flew away before having reached the sham. nectaries, and the flower visited by it was found without pollen on the stigmas, and with both pollinia in their cells. Nevertheless, it is most probable that this fly, if not disturbed by my approach, would have stepped forwarcl on the labellum, and, trying one of the sham-nectaries, would have removed one of the pollinia and perhaps transferred to the stigma of another sten, in the manner described by Charles Darwin ("Fertilisation of Orchids," p. 47).

For observing the fluid secreted by the labelium it may be essential to examine plants in their native habitats, not plucked ones.

Lippstadt

Hermann Müller

\section{The Jura}

Is the midst of the enjoyment of quiet and beautiful scenery I camnot refrain from writing, in the interest of geology, to attract attention to the facilities for the study of the Jura range afforded by a railway recently opened from I3âle, vid Délémont and the Miinster Thal, to Bienne. It crosses the range at, relatively to the anticlinal, a considerable angle, necessitating no less, as I am told, than twenty-five tunnels great and small (I did not count them myself).

Consequently, in a short morning's railway ricle the traveller sees a vast deal of Jurassic structure, added to which the Minster 'Thal, formerly a rather tiring clay and a half's drive, is replete with rock, forest, and pasture scenery of very great beatity.

Travellers thus crossing the Jura on their way to the Alps and returning from Lausanne by Vallorbes to Paris, will thank me, I think, for pointing out what, if only from a scientific point of view, are two recently-developed routes, far more interesting than the customary approaches to this land of wonders. repress poetic and mountaineering sympathies.

Pension Mounoud, Veytaux-Chillon, Marshall Hali Canton Vaud, June 2I

\section{THE TRANSIT OF VENUS PHOTOGRAPHS}

THE photographs which have been measured were taken with the five photoheliographs made by Mr. Dallmeyer for the Transit of Venus expeditions, on "patent plates" 6 inches square, the images of the sun being very nearly 3.9 inches in diameter. The dry process of Capt. Abney was used throughout.

The measuring instrument, the determination of the errors of its glass millimeter scale, and the method of obtaining the optical distortion of the photoheliographs, have already been described in the Society's Proceedings. It has been found by an elaborate investigation that the lines of equal distortion were sensibly circles concentric with the centre of the field. The actual correction for distortion for that zone of the field in the points to be measured generally fell, was exhibited on the board, and was almost identical for all five instruments.

Before commencing the measures of a negative, the position of the line of centres was marked upon the film by a simple mechanical process. This operation has been performed independently by Mr. Burton and myself,

I Paper read by Capt. Tupman at the meeting of the R.A.S. on June ${ }_{4}$, on the measurements of the Transit of Venus photographs. with no sensible difference. I have paid no attention to the marks left by Mr. Burton on the plates, and found that my own coincided with them in direction.

In placing the negative in the instrument the circular carrier was turned about until the line of centres was truly parallel to the direction of the sliding motion of the microscopes.

When the negatives are placed under the microscope with an amplification of only five or six diameters, the limbs of both planet and sun, even those which are pretty sharp to the unaided eye, become extremely indistinct, and the act of bisecting a limb with the wire or cross of the micrometer is mere guess-work. The deposit of silver fades off gradually to nothing, and the denser the film the broader generally is the zone of fading off and the more uncertain the measures. In many cases the difficulty is aggravated by ruggedness due to atmospheric disturbances, but the smooth and gradual fading off is the chief cause of uncertainty.

There is only one really sharp picture in the whole col lection, including the Indian and Australian contingents, and that is one of Capt. Waterhouse's wet plates, taken at Roorkee with a Dallmeyer instrument precisely similar to the others.

It should be remarked that in these instruments the artist has attempted to unite the photographic and visual foci on the collodion film. No doubt some sharpness of the photographic image was thus sacrificed, but this has little or nothing to do with the unfortunate failure of the photography generally.

Each photograph has been measured six times by $\mathrm{Mr}$. Burton and six times by myself. I am not able to include in my series of measures all the photographs measured by Mr. Burton, for the reason that when some of them were viewed throuth the microscope I could see nothing to bisect, either from the extreme faintness of the film, or from its too gradual fading off.

Mr. Burton generally employed a cross of webs, but I have preferred a single very fine web, the breadth of urhich was eliminated in the mean by the mode of bisecting.

It had been suggested that the measuring instrument should possess the power of rotating the sun's image about a mechanical centre. This would be useful in some cases of rugged limbs when the sun's image was not rendered elliptical by refraction, but in my opinion would make no material difference in the accuracy of measurement. The rotation could only be applied to the limbs of the sun, whereas, perhaps, the greatest difficulty had been at the limbs of the planet.

From the measures, corrected for distortion, were obtained the 'photographic diameters of the sun and of Venus; the former presumably enlarged, the latter diminished by irradiation in a sensibly equal degree. The sum of the measured diameters in millimetres was compared with the sum of the tabular diameters, subject to errors, for the scale value, and thus every photograph furnished its own scale.

The measured distance of centres affected by errors of semi-diameter was then compared with the tabular distance affected by errors of parallax, right ascension, and north polar distance. From each photograph was formed an equation involving all the unknown quantities, of which the errors of parallax and of semi-diameters were the more important.

The rigorous solution of the equations resulting from

Mr. Burton's measures is,

$$
\begin{aligned}
\text { Mean solar parallax } & =8^{\prime \prime} \cdot 165-\cdot 209(d R+d r) \\
, \quad d \text { R.A. } \ldots & =+5 \cdot 38+\cdot 287(d R+d r) \\
, \quad d \text { N.P.D. } . . & =-5 \cdot 10-.882(d R-d r) .
\end{aligned}
$$

The parallax deduced being absurdly small-altogether inadmissible, indeed-the Astronomer-Royal suggested that the quantity $(d R+d r)$, or the sum of the corrections to the tabular semi-diameters, should be considered the 
only unknown, and that approximate values of the true solar parallax and of the errors of R.A. and N.P.D. should be substituted in the equations. This was done, the mean solar parallax being taken at $8^{\prime \prime} \cdot 85, d$ R.A. as $+5^{\prime \prime} \cdot 8$ r, $d$ N.P.D. as $-5^{\prime \prime} \cdot 33$, which values resulted from the general solution of the whole of the contact observations, and the following values of $d R+d r$ were obtained :--

\begin{tabular}{|c|c|c|c|c|}
\hline Station. & $\begin{array}{l}\text { By Purton's } \\
\text { Measures. }\end{array}$ & $\begin{array}{c}\text { Number } \\
\text { of Photo- } \\
\text { graphs } \\
\text { Meaiured. }\end{array}$ & $\begin{array}{l}\text { By Tupman's } \\
\text { Measures. }\end{array}$ & $\begin{array}{l}\text { Number } \\
\text { of Phot\%. } \\
\text { graphs } \\
\text { Measured. }\end{array}$ \\
\hline $\begin{array}{rrr}\text { Luxor } & \ldots & \ldots \\
,, & & \\
,, & & \end{array}$ & $\begin{aligned} & a \cdot 96 \\
- & -1 \cdot 18 \\
- & 2 \cdot 21\end{aligned}$ & $\begin{array}{l}\text { II } \\
\text { II } \\
\text { II }\end{array}$ & $\begin{array}{l}-0.13 \\
-1.61 \\
-\end{array}$ & $\begin{array}{l}12 \\
11 \\
-\end{array}$ \\
\hline 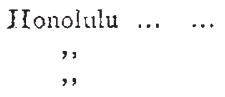 & $\begin{array}{l}-1.29 \\
-1.75 \\
-0.7 x\end{array}$ & $\begin{array}{l}\text { II } \\
\text { II } \\
\text { IO }\end{array}$ & $\begin{array}{l}-0.21 \\
-0.54 \\
-\end{array}$ & $\begin{array}{l}12 \\
12 \\
-\end{array}$ \\
\hline 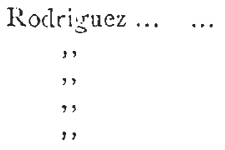 & $\begin{array}{l}+1.19 \\
+0.23 \\
+2.10 \\
+0.14 \\
+1.46\end{array}$ & $\begin{array}{l}\text { II } \\
\text { 10 } \\
10 \\
\text { It } \\
\text { II }\end{array}$ & $\begin{array}{l}+2 \cdot 44 \\
+2 \cdot 49 \\
+2 \cdot 74 \\
+1 \cdot 27 \\
+2 \cdot 36\end{array}$ & $\begin{array}{r}9 \\
6 \\
8 \\
10 \\
9\end{array}$ \\
\hline Bumlam, N.Z... & +0.68 & ${ }^{13}$ & $\begin{array}{l}+I^{3} 89 \\
+I^{\prime} 38\end{array}$ & $\begin{array}{r}3 \\
10\end{array}$ \\
\hline Kerguelen ... ... & $+r^{-5} \mathrm{I}$ & 8 & - & o \\
\hline
\end{tabular}

The above is perhaps the best way to exhibit the nature of the discordances. They might also have been shown as apparent errors of the tabular distance of centres.

The discordances of any one station are too large to admit of the measures being employed with advantage for the determination of the solar parallax. They are due to inherent defects of the photographic images. The reason why at the two northern stations the signs are all minus, while at the three southern they are all plus, is at present obscure, and I am not prepared to offer any suggestion as to the cause.

\section{THE NORWEGIAN NORTH ATLANTIC EXPEDITION}

I

SEND you inclosed a clip from the Dagbladet, containing the route of our expedition for the coming summer. I hope to be able to send you notes from our expedition during our several stays in Hammerfest.

H. MOHN

"According to the plan of this expedition, the Voeringen was to start from Bergen on its third and last cruise on the 15 th inst. It will probably have reached Tromsoe by the rith inst., and, after taking on board a pilot acquainted with the northern waters, have immediately proceeded to Alten Fiord, mainly to inspect the meteorological station there, and to examine the animal and plant-life of the Fiord bottom. The magnetic observations required for regulating the compasses, \&c., were to be made at Hammerfest between the $2 \mathrm{r}$ st and 24 th inst. The course was then to be set eastwards, in order to examine the relations of depth and animal life, \&c., in two of the fiords of Finmark. After touching at Vardoe on the 27 th, the voyage is to be continued to a point midway between Vardoe and Novaya Zemlya, in order to take soundings and determine the boundary of the ice-cold water in the East Polar Sea, which hitherto in these regions has only been observed at Bear Island by the well-known Austrian Polar explorer Weyprecht, in his excursion thither several years ago in the Tromsoe yacht Samison. This thorough examination of the sea off the north-east coast of Norway, towards Novaya Zemlya will be of special importance for the study of the migrations of the "lodde" (Malotus arcticus), as it is probable that it is there that this salmon-like fish has its abode whence in spring it makes its way in large shoals to the coast of Finmark to spawn, pursued by the cod, which follows it and is accordingly taken; while the so-called "lodde" fish, as is well known, is not fished for, because it is not suitable for human food, on account of its penetrating unpleasant odour.

This eastward cruise of the Voeringen will scarcely occupy more than ten days, as the sea is here so shallow that taking soundings, \&c., need not occupy much time, and the Voeringen may accordingly be expected back at Hammerfest on July 7 , to take on board coal, water, \&c., for a new cruise to the west ward in the navigable waters north of Jan Mayen, which the expedition visited last year; thence to the Greenland ice, where the seal fishing is usually carried on, in order to ascertain the boundary between the Greenland Polar current and the Gulf Stream. The stretch of sea that will be traversed by the Voeringen has not hitherto been surveyed, and here will doubtless be found, by means of the lead, the beginning of the great Polar sea-depth which runs in between Greenland and Spitzbergen. The Voeringen will then return to Hammerfest to make preparations for the third cruise.

This cruise, which will be the last, will be commenced on July 29 , and be occupied with the survey of the navigable waters between Bear Island and Spitzbergen, where the well-known shark fishing is prosecuted, and the great sea-deeps off the west coast of Spitzbergen $\left(76^{\circ}\right.$ to $80^{\circ}$ $N$. lat.) which hitherto have only been surveyed, and that incompletely, by two of the Swedish expeditions. The Voeringen will go as far north as it can for ice, but there is certainly no great expectation that the Norwegian expedition will be successful in carrying off the prize in the competition with other nations to reach the North Pole, for the Voeringen will certainly soon meet with ice in the navigable waters on the north coast of Spitzbergen, and it is not fitted out for a North Pole expedition. Leaving it to the enterprising publisher of the New York Herald and others to endeavour to reach this goal, the Voeringen will, instead, after having turned southwards, survey the fiords and banks on the west coast of Spitzbergen. There the Norwegian fishermen, as is well known, carry on a not inconsiderable cod-fishing, the yearly catch numbering 300,000 to 400,000 fish. But if we keep in view the recent discovery of the great fishing bank off the Lofoten Islands, it will be seen that the fishermen need not undertake the long and troublesome voyage to Spitzbergen to catch cod. They will find superabundence of larger and better fish at the banks off Vesteraalen, so to speak, lying before their own door. But these Lofoten fishing banks are for the time being visited by the Norwegian fishermen as little as the bank abounding in fish which lies off the Froey Islands (north-west of the mouth of Trondhjem Fiord), although the latter was known to old fishermen. The surveying-steamer Hansteen has now mapped it. It is besides beyond all doubt that one of the practical results of the Norwegian North Atlantic Expeditions will be a better turning to account of the rich fishing banks of whose position, animal and plant life, more precise information has now been obtained.

The return from Spitzbergen will take place at the end of August, and the Voeringen, after having touched at Hammerfest or Tromsoe, and Bergen, where the members of the expedition resident there will land will 